\title{
Erratum to: Pericruciate fat pad of the knee: anatomy and pericruciate fat pad inflammation: cadaveric and clinical study emphasizing MR imaging
}

\author{
Abdalla Youssef Skaf • Guinel Hernandez Filho • \\ Berna Dirim • Mani Wangwinyuvirat • Debra Trudell • \\ Parviz Haghighi • Donald Resnick
}

Published online: 18 December 2012

(C) ISS 2012

Erratum to: Skeletal Radiol (2012) 41:1591-1596

DOI 10.1007/s00256-012-1447-9

The original version of this article unfortunately misspelled the name of "Parviz Haghighi" and is now corrected in the author group of this article.

The online version of the original article can be found at http://dx.doi.org/ 10.1007/s00256-012-1447-9.

\footnotetext{
A. Y. Skaf

Department of Radiology,

Hospital do Coração (HCor),

Rua Desembargador Eliseu Guilherme, 147, São Paulo, SP,

Brazil 04004-030

e-mail: abskaf@gmail.com

G. H. Filho $(\square)$

Department of Radiology,

Santa Casa de São Paulo Hospital,

Rua Cesario Motta Jr.,112, São Paulo, SP,

Brazil 01221-020

e-mail: guinel31@gmail.com

B. Dirim

Department of Radiology,

Izmir Atatürk Training and Research Hospital,

Cihar Dudayev Bulvarı Soyak Mavișehir II. etap,

B4 Blok, D:42, Karşıyaka, İzmir, Turkey 35550

e-mail: bernadirim@gmail.com
}

M. Wangwinyuvirat

Department of Radiology, Rajavithi Hospital, 2 Rajavithi Road,

Phayathai Rajathevee, Bangkok 10400, Thailand

e-mail: wmani2006@gmail.com

D. Trudell $•$ D. Resnick

Department of Radiology, Veterans Affairs Medical Center,

University of California, San Diego,

CA 3350 La Jolla Village Drive, La Jolla, CA 92161, USA

D. Trudell

e-mail: dtrudell@ucsd.edu

D. Resnick

e-mail: dresnick@ucsd.edu

P. Haghighi

Department of Pathology, Veterans Affairs Medical Center, University of California, San Diego,

CA 3350 La Jolla Village Drive, La Jolla, CA 92161, USA

e-mail: phaghighi@ucsd.edu 